Andréa Gazzinelli 1 Márcia Christina C. Souza 1 Iara Nascimento 1 Il céia Ribei ro Sá 1 Matilde Meire Miranda Cadete 1 Helmut Kloos 2

\section{Domestic water use in a rural village in Minas Gerais, Brazil, with an emphasis on spatial patterns, sharing of water, and factors in water use}

\author{
Utilização doméstica de água em comunidade \\ rural de Minas Gerais, Brasil e sua relação com \\ fatores sócio-econômicos, ambientais, e espaciais
}

1 Departamento de Enfermagem Materno Infantil e Saúde Pública, Escola de Enfermagem, Universidade Federal de Minas Gerais. Av. Alfredo Balena 190 Belo Horizonte, MG 30130-100, Brasil.

2 Department of Epidemiology and Biostatistics, University of California Medical Center, 94143, San Francisco, California, USA.

\begin{abstract}
This paper examines the relationship between domestic water use and socioeconomic, environmental, and spatial parameters at the household level in a small rural village in northern Minas Gerais State. Five methods are used - direct observation, household interviews, self-reporting by households, regression analysis, and statistical mapping. Results show that water use is characterized by 1 ) generally low but widely fluctuating values per person per day, 2) sharing of water sources between households, 3) the use of multi ple sources by individual households, 4) avoidance of heavily contaminated stream sites, and 5) predominance of socioeconomic factors in water use. Households owning their own water supply used, on average, 25.3 liters per person/day and those without a supply 9.0 I, with higher use of the local streams among the latter. Water use varied spatially. The soci oeconomic factors house qual ity, Iatrine ownership, type of water source, and a utility index were si gnificantly correlated with water use. Implications of these simple household water sources and the more deficient sanitary facilities for potential water-borne disease transmissi on are bri efly discussed and suggestions made for further improvements. This study confirms the appropriateness of the application of direct observation, interview, and microgeographical methods for quantitative water use studies.

Key words Domestic Water Consumption; Rural Water Supply; Water Quantity
\end{abstract}

Resumo Este trabal ho teve como objetivo estudar a relação da utilização doméstica de água com fatores sóci o-econômicos, ambi entais e espaciais em comuni dade rural do nordeste de Minas Gerais. Utilizamos observação di reta, entrevistas, questionário, análi se de regressão e mapas estatísticos. Os resultados mostraram que a utilização da água é caracterizada por 1) valores geralmente baixos mas altamente flutuantes por pessoa/dia; 2) uso comum das fontes de água entre famílias; 3) uso de várias fontes de água; 4) não utilização de locais altamente contaminados dos córregos e 5) predomi nância defatores sóci o-econômicos. Os domi cíli os que possuem fonte própria deágua utilizaram, em média, 25,3 litros por pessoa/dia e aquel es sem fonte própria, 9,0 I, com o último grupo utilizando mais as águas dos córregos. O uso deágua apresentou, ainda, variação espacial. Os fatores sócio-econômicos, condições de moradia, presença de fossa, ti po de água e índi ce de bens de consumo foram relacionados significativamente ao uso de água. Os dados sugerem uma rel ação entre fonte de água, con dições sanitárias e a ocorrência de doenças transmi tidas pela água. Este estu do confirma a adequação dos métodos mi crogeográficos, de observação direta e de entrevista para os estudos quantitati vos sobre utilização de água.

Palavras-chave Consumo Doméstico deÁgua; Abastecimento Rural deÁgua; Quantidade de Água 


\section{Introduction}

Not only quality but also quantity of domestic water supplies impacts on human health. The review by Esrey \& Habicht (1986) of 65 epidemiological studies on the health effects of improved water supplies and sanitation facilities indicates that quantity of water is often more important than quality, particularly in heavily contaminated environments. Many rural communities in the poorer, northern part of Brazil lack safe water supplies (Giugliani,1989). Water consumption correlates with size of communities and varies between regions. In 1980, total water use varied from 350-450 liters per capita per day in São Paulo and Rio de Janeiro and 250 liters in Curitiba to 200 liters in the large cities, 150 liters in medium-sized cities, and 100 liters in small towns of the northeast (Tonilio, 1982). Metered consumption in São Paulo in 1988 was 237 liters per capita per day and 211 liters in Brasília (Yepes \& Diandera, 1996). Rural communities in Latin America have been estimated to use 40 liters per capita per day from standpipes, considerably below the 100-190 liters used by urban households from piped connections (Saunders $\&$ Warford, 1976). The lowest consumption levels have been reported from rural African communities (1-25 liters per capita per day), significantly below the USAID recommended target of 20-40 liters per capita per day (USAID, 1982; Teka, 1993).

Most water use studies in Brazil have focused on engineering aspects of large urban water systems and few on socioeconomic aspects of rural water sources, even though the highest prevalence rates of water-related diseases are found in rural communities. The urgency of providing improved water sources is also indicated by various health benefits they can confer, ranging from the reduction in the incidence of dysentery, schistosomiasis, and other water-related infectious diseases to secondary impacts, such as promotion of community participation in primary health care (Eng et al., 1990; Mohundwa, 1986). Current efforts to develop a viable primary health care program in Brazil (Haines, 1995) may further increase the need for relevant information on domestic water use in rural areas.

Studies in various tropical regions have shown that the type, location, season, use patterns, and maintenance of improved and semiimproved domestic water sources affect the quality and quantity of water available to rural households (Cairncross, 1989; White et al. 1972). Whereas the problem of frequent hand pump breakage is well-known, there is little information on other factors in rural water use, such as preference for different water sources and sharing of the same sources by different households (Gorter et al.,1995; Saunders \& Warford, 1976). Similarly, few studies worldwide and none in Brazil have studied quantitatively the use of multiple improved and semiimproved water sources by the same households. But this information is needed if community participation is to contribute to the planning, implementation, and maintenance of water supply systems (Sawyer, 1996). Lastly, there is a need to develop methodologies for the study of rural water use that permit comprehensive analysis of the problem and comparability of the results by different investigators.

The objective of this paper is to examine domestic water use in Nova União village in Itabirinha de Mantena Município, Minas Gerais State in Brazil, a subsistence agricultural community of about 200 people. The focus is on quantifying water obtained from all sources by households in relation to socioeconomic, environmental, and distance factors and on evaluating several data-collecting and analytic methods. Daily and seasonal variations in water use and amounts used for different domestic activities are examined in a separate paper. This study forms an integral part of an ongoing epidemiological and human behavioral investigation of schistosomiasis with a health education intervention in Nova União and the neighboring village of Boa União. Results of this study may also be useful to planners designing water supply systems for small rural communities in poorer areas of Brazil.

\section{Methods}

Water sources, frequency of contacts, and quantity of water

One 7-day water contact survey using the direct observation method described by WHO (1979) and Kloos et al. (1990, 1997a) and a questionnaire survey covering all households in Nova União were carried out in July (dry season) 1996. A second, more comprehensive water contact survey covering not only the frequency, duration, and location of water contacts but also the quantity of water drawn by households without a water source was carried out in November (rainy season) 1996. Six local grade school students were selected with the assistance of community leaders and employed 
for half-day shifts to observe and record all water contact activities at 24 sites for 7 consecutive days between 7:30 A.M. and 5:30 P.M. These sites were at streams, wells, protected springs, rubber pipes bringing water from springs, fish ponds, and a play pond constructed by children (Figure 1). The observers, each of them assigned to specific contact sites, recorded on forms the names, age, sex, and house number of all persons coming in contact with water at these sites, the type of water contact activity (washing clothes, fetching water, washing hands, face or feet, bathing, washing utensils, stream crossing, fishing, playing, irrigating gardens, and "other activities"), duration of each contact, and the site used. Random spot checks of observation and recording activities were made daily, and water use before and after the observation period was observed on 4 days by one of the investigators (H.K.) for quality control. A census list was used to delete from the study all persons not living de facto in the 39 households included in the study.

Because the water use of households with their own water supply could not be effectively observed, they were interviewed twice a day (between 11:30 A.M.-12:30 P.M. and 5:30 P.M .6:30 P.M.) during the 7-day study in November about the quantity of water (in liters) they had used during the day for different activities. In addition, the female heads of 4 households were asked to record on forms the quantity of all water used for individual activities carried out in the house for a 3-day period.

Three households which were temporarily absent as well as 1 household with unreliable November water use data were excluded from this study. Two other households, located outside the village proper, were permanently excluded for logistic reasons.

\section{Socioeconomic and environmental factors}

Focus group discussions were held in July 1996 among 3 groups each consisting of school-aged children and adult men and women with the objective of identifying the major health and economic problems in Nova União, as well as patterns and problems of domestic water use and as background for the questionnaires. Unstructured interviews among informants who were repeatedly visited during the 4 trips to Nova União in 1996 provided detailed information on water sharing practices, social patterns, and the construction and maintenance of improved water supplies and latrines. A pre-tested questionnaire was administered by 2 of the investigators (A.O. and M.C.) to all households in August 1996. This informed on socioeconomic level, demographic patterns, water sources used for different activities throughout the year, environmental sanitation, household income, and demographic parameters.

A utility index was constructed for each household as a measure of wealth based on material possessions, due to the common problem of obtaining reliable information on income in rural areas and the effective use of such indices by other investigators of rural water use (White et al., 1972). Each variable incorporated into this index was assigned different scores for quantitative analysis, as follows: no utilities owned ( 0 score), radio ( 1 ), radio and wood fuel for cooking (score 1 each), gas for cooking and video (2 each), electricity for cooking and TV (3 each), refrigerator (4), motorcycle (5), car (6), land ownership (7).

A house quality index was also developed as a measure of material wealth and environmental sanitation by integrating quality of house floor (dirt floor score 1, wood 2, concrete 3 , ceramic tile 4), walls (wood stick/mud 1 , wood 2, concrete 3, tile 4), roof (wood 1, corrugated steel 2, asbestos 3, tile 4) and environmental sanitation and house maintenance, both inside the house and outside (very dirty and poorly maintained 1 , medium 2 , very clean and well maintained 3 ). The information on wealth was obtained from household interviews and on environmental sanitation and house maintenance from direct observation by interviewers.

\section{Distance}

Maps were prepared of the location of all occupied houses, streams, and their water contact sites, fish ponds, wells, springs, piped water outlets, latrines, and fences (Figure 1). The frequency and duration of all contacts and of fetching water outside the home were mapped. The distance traveled by household members to fetch water was calculated using the straight line method, which has been successfully applied in various water contact studies (Kloos et al., 1983, 1997).

\section{Quantitative analysis}

Simple correlation and multiple linear regression analyses (forward stepwise) were carried out to examine the relationship between per capita water use and socioeconomic, environmental, and distance variables. 
Figura 1

N ova União: study households and water sources.

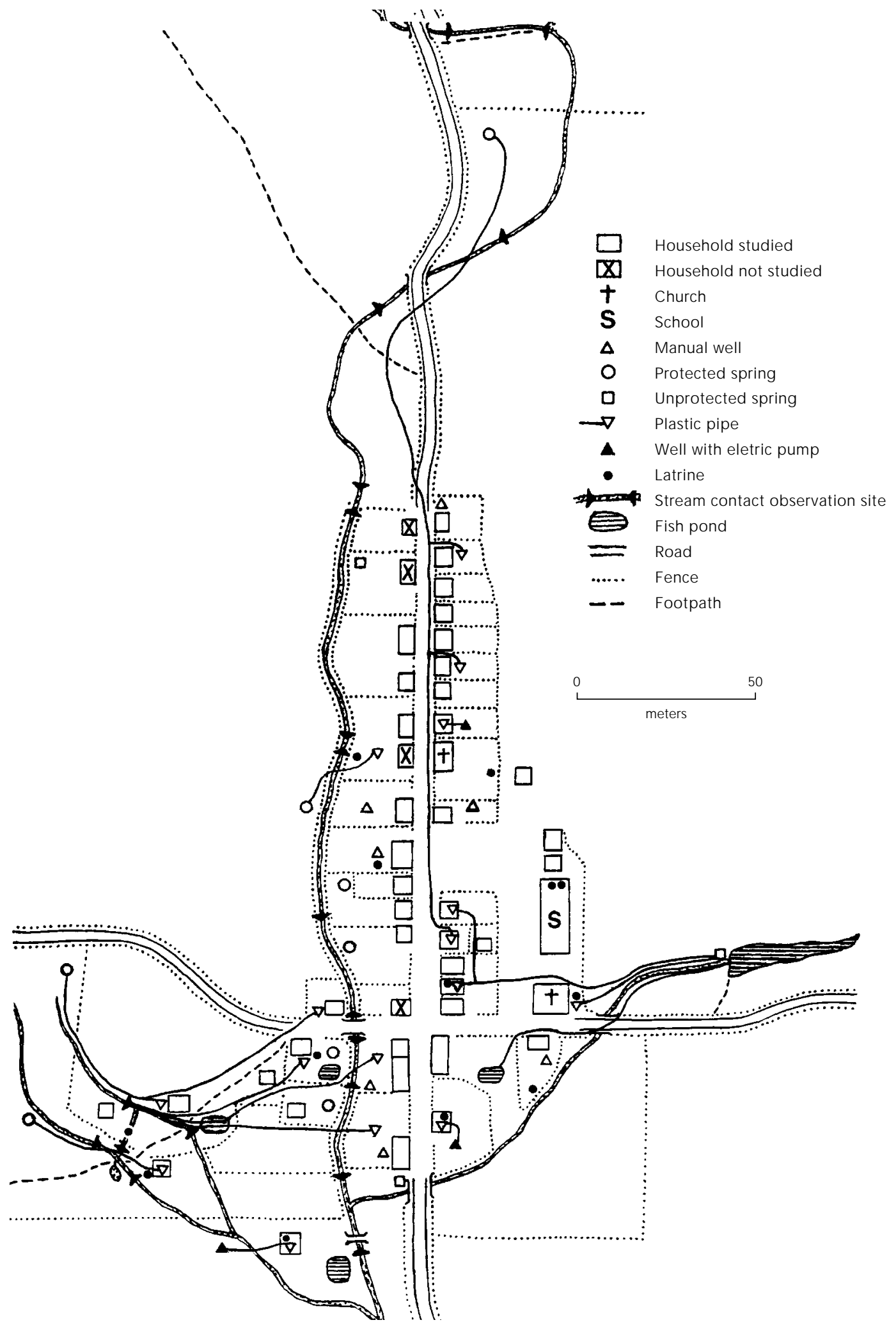




\section{Results}

Study community, population, and water supply

Nova União has nearly 200 people, based on our 1996 census. Daily farm labor and sharecropping in coffee, beans, maize, and rice, as well as cattle ranching on small and mediumsized farms (fazendas) are the main sources of income. The village is only about 30 years old, and the original settlers and their descendants, most of whom originated on nearby fazendas, form a social nucleus. Nova União has no public services besides a grade school teaching grades 1-4, electricity, and a bus service to the center of Itabirinha de Mantena Município (County) and other nearby towns. All households developed their own water sources using their own resources without government or NGO (nongovernmental organization) support. Twenty-four of the 39 households had wells, protected springs, and piped spring water; the remaining households obtained their domestic water from these owners or from the streams. Only 10 households, the 2 churches and the school had latrines, all of the pourflush type which discharged via plastic pipes into the nearby streams (Figure 1). The poverty of most households necessitates that school children frequently work in agriculture, a major factor in the low educational level of the population. Many young people migrate to towns in search of non-farm jobs, but births and new settlers maintain a low population growth rate.

\section{Quantity of water used}

A total of 20,918 liters drawn from all sources were recorded by direct observation and the household surveys for the 35 study households. Mean quantities per household were 820.7 liters for households owning water sources and 220.2 liters for those lacking a source but amounts drawn by individual households ranged from 20 to 1,592 liters. Mean amounts per capita per day were 25.3 liters for owner households and 9.0 liters for non-owner households, with 8 households in the latter using less than 10 liters and 4 households in the former using more than 40 liters. Total amounts were significantly smaller, on average, for wells with electric pumps than manual sources $(p \varangle 0.05)$, although the largest per capita amounts (70.5 liters) were used by a household using a well with a pump. An estimated $85 \%$ of all water used for domestic purposes in November came from improved sources and 15\% from the streams, although quantities of water used during activities carried out at the streams cannot be reliably quantified. These estimates are based on the frequency and duration of different types of water contact activities and estimates of the actual amount of water used (Figures 2 and 3). Direct observation showed that more than $99 \%$ of all water was fetched from improved sources and only $0.7 \%$ from the streams, mostly for washing clothes and house cleaning. Non-owners obtained larger amounts from the streams than owners (Table 1).

Self-reporting of water used during 2 days in the home by 4 households owning a water source showed that $41 \%$ of the total 1,794 liters drawn were used for personal hygiene (bathing mostly, also washing hands and other parts of the body, and laundering), 33\% for cooking, drinking, and washing of utensils, and $24 \%$ for environmental sanitation (washing floors and flushing toilets).

O wnership of water sources, social relations, and sharing of water

Use of water from improved sources in other houses and of streams varied considerably among households and between the owner and non-owner groups. Ten of the 22 households with a source shared their water with households lacking a source. Two of the owners shared with as many as 7 other households, mostly non-owners. Some owners also used water from neighbors and relatives. Most nonowners and owners using water from other households used more than one and as many as 4 sources (Figure 3 ). According to informants, water sharing was based mainly on kinship, social relations and cost-sharing arrangements. Whereas water from wells and springs was shared free of charge, some households shared the cost of installing plastic pipes from springs, 2 of which supplied 3 households each (Figure 1). The well of the household owning a small store in the center of the village was the most heavily used source. In the downstream half of the village, particularly below the cross street where the first settlers reside, most water was shared with relatives (Figures 2 and 3 ). Use of the sources in the neighborhood with an abundant supply of water also provided for gossip during the lengthy laundering activities and for adolescent girls to be seen by boys. Wells were generally preferred over protected springs for drinking and cooking as their water was considered to be cleaner coming from a deep source but 2 well owners away 


\section{Figura 2}

N umber of water contacts with the streams per household. A: households owning a water source;

B: households not owning a water source.
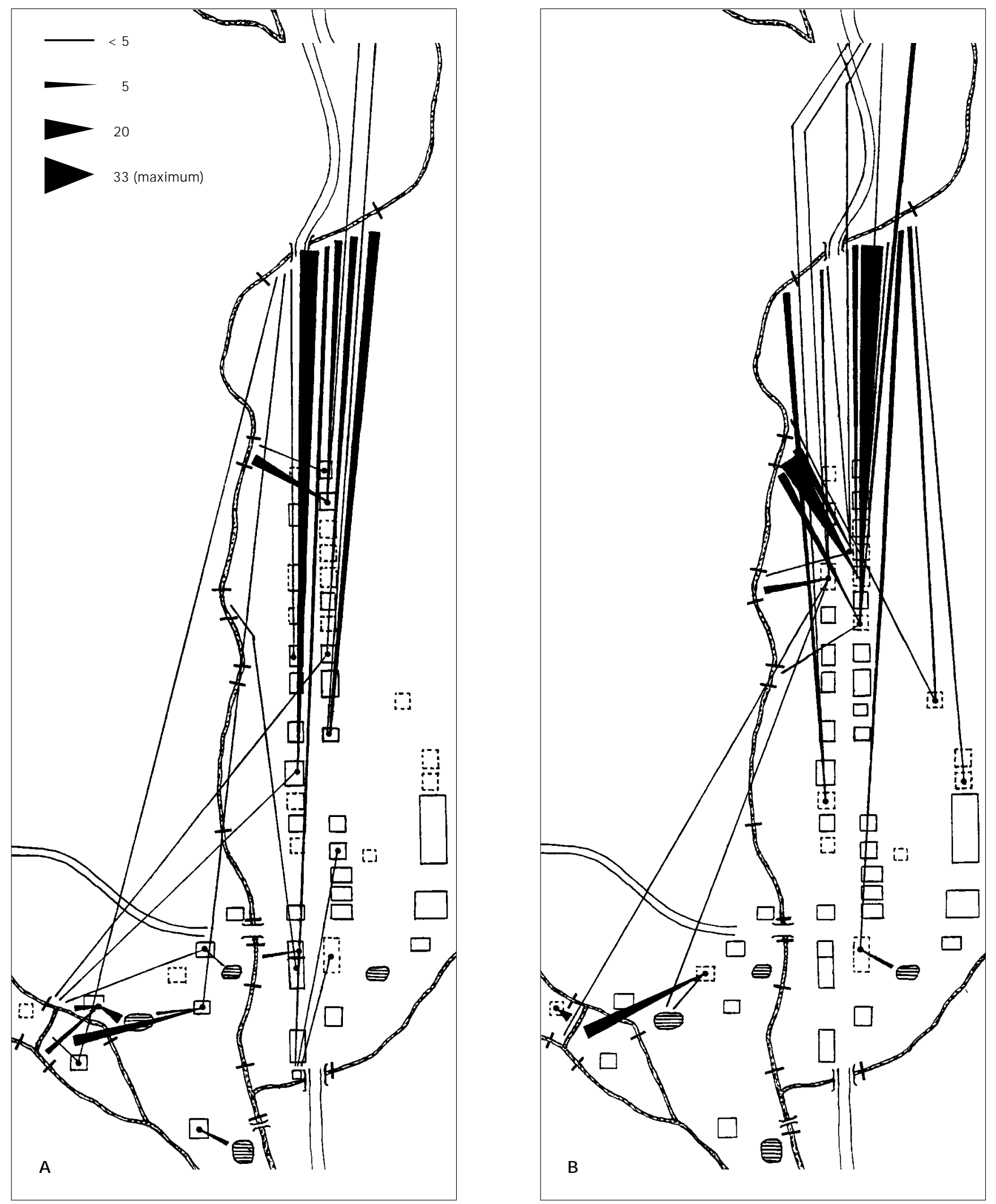


\section{Figura 3}

Q uantity of water (in liters) obtained by households from neighbors or relatives. A: households owning a water source;

B: households not owning a water source.
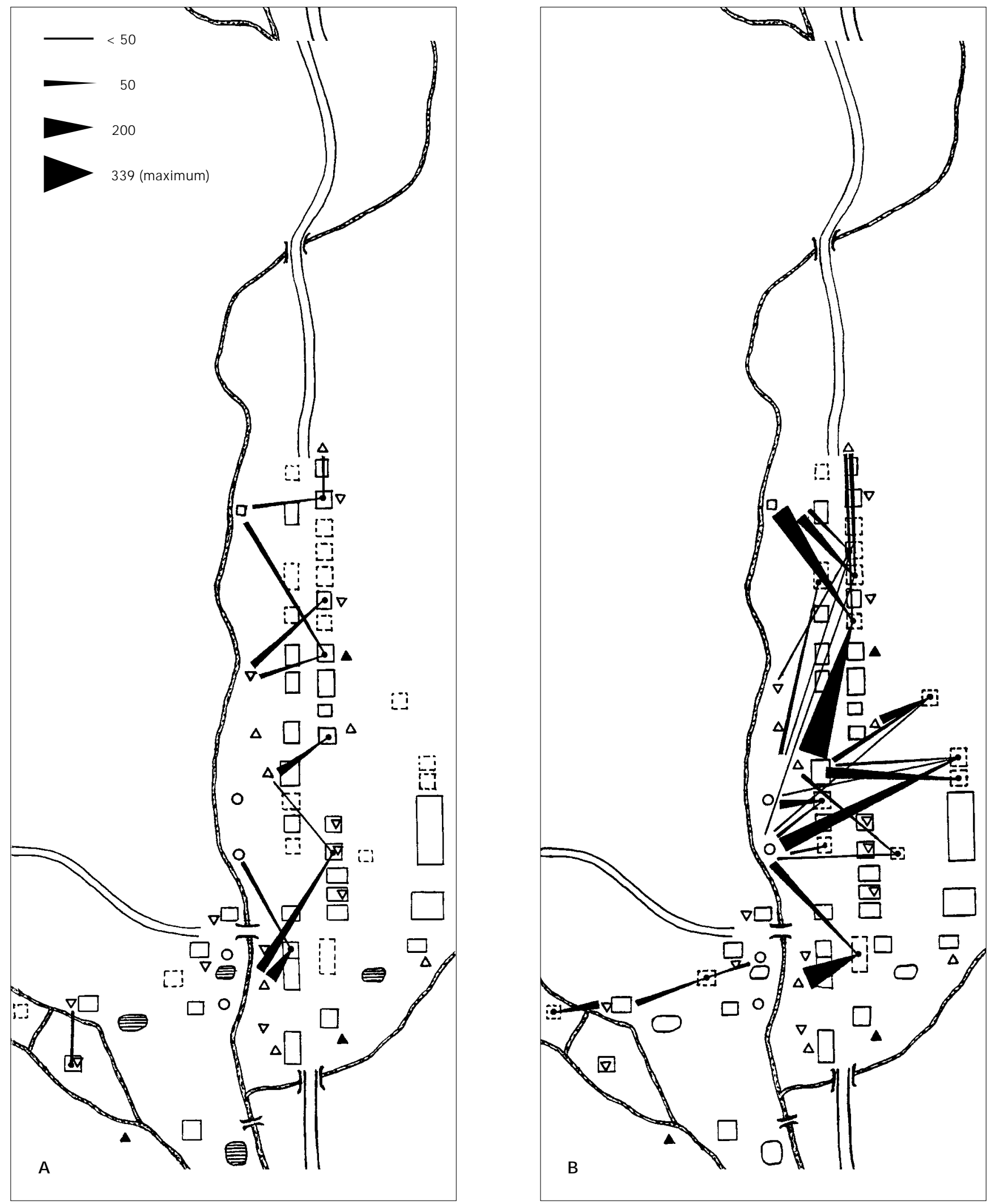
Table 1

Total quantity (liters) of water fetched from all sources and from streams by 22 households owning water sources and 13 households without sources during 7 days in relation to type of water source and number of persons per household.

\begin{tabular}{|c|c|c|c|c|c|}
\hline Household no & Water source owned & no of persons & Total quantity & Streams (\%) & Liters/person/day \\
\hline \multicolumn{6}{|l|}{ Owners } \\
\hline 1 & Well, manual & 2 & 451 & $9(2.0)$ & 32.2 \\
\hline 2 & Well, manual & 5 & 1,592 & 0 & 45.5 \\
\hline 3 & Well, manual & 8 & 1,005 & 0 & 17.9 \\
\hline 4 & Well, manual & 9 & 753 & 0 & $20.9 *$ \\
\hline 6 & Well with pump & 3 & 382 & 0 & 18.2 \\
\hline 7 & Well with pump & 9 & 836 & $14(1.7)$ & $15.5^{*}$ \\
\hline 8 & Protected spring & 6 & 1,188 & 0 & 28.3 \\
\hline 9 & Protected spring & 6 & 1,306 & 0 & 31.1 \\
\hline 10 & Protected spring & 7 & 414 & 0 & 8.4 \\
\hline 11 & Pipe from spring & 2 & 535 & 0 & 38.2 \\
\hline 13 & Pipe from spring & 2 & 371 & $34(9.2)$ & 26.5 \\
\hline 14 & Pipe from spring & 3 & 1,266 & 0 & 60.3 \\
\hline 15 & Pipe from spring & 4 & 753 & 0 & 26.9 \\
\hline 16 & Pipe from spring & 4 & 932 & 0 & 33.3 \\
\hline 17 & Pipe from spring & 5 & 692 & 0 & 19.8 \\
\hline 18 & Pipe from spring & 6 & 1,561 & $36(2.3)$ & 37.2 \\
\hline 19 & Pipe from spring & 6 & 467 & 0 & $13.0 *$ \\
\hline 20 & Pipe from spring & 7 & 418 & 0 & 8.5 \\
\hline 21 & Pipe and manual well & 2 & 640 & 0 & 45.7 \\
\hline 22 & Pipe and manual well & 5 & 1,142 & 0 & 32.6 \\
\hline \multicolumn{6}{|l|}{ Non-owners } \\
\hline 1 & None & 1 & 108 & $36(33.3)$ & $18.0 *$ \\
\hline 2 & None & 1 & 20 & 0 & 2.9 \\
\hline 4 & None & 2 & 82 & 0 & 5.9 \\
\hline 5 & None & 3 & 286 & $2(0.7)$ & 13.6 \\
\hline 6 & None & 3 & 181 & 0 & 8.6 \\
\hline 7 & None & 4 & 202 & 0 & 7.2 \\
\hline 8 & None & 4 & 112 & $10(8.9)$ & 4.0 \\
\hline 9 & None & 4 & 213 & $5(2.3)$ & 7.6 \\
\hline 10 & None & 5 & 158 & 0 & 4.5 \\
\hline 11 & None & 5 & 617 & $9(1.5)$ & 17.6 \\
\hline 12 & None & 6 & 164 & 0 & 3.9 \\
\hline 13 & None & 6 & 564 & 0 & 13.4 \\
\hline $\begin{array}{l}\text { Owners subtotal } \\
\text { (mean per household) }\end{array}$ & & $105(4.0)$ & $18,055(820.7)$ & $93(0.5)$ & $(25.3)$ \\
\hline $\begin{array}{l}\text { Non-owners subtotal } \\
\text { (mean) }\end{array}$ & & $46(3.5)$ & $2,863(220.2)$ & $62(2.2)$ & $(9.0)$ \\
\hline
\end{tabular}

* These households were absent for one or more days during the study period and we calculated their water use for only the days they were in Nova União. 
from the main stream complained of inadequate, poor quality supplies and used wells nearer to the stream to meet their needs (Figure 3).

The sharing of the manually operated wells and pipes with neighbors and relatives contrasts with the restrictive use of wells with pumps. The owners of these wells mentioned the high cost of electricity as the reason for not sharing them with other households. This is also indicated by the low per capita use in 2 of the 3 households owning wells with pumps (Figure 2). More recent installations of electric pumps in additional households have resulted in additional changes in water use patterns, which will be reported separately.

\section{Distance}

Distance between households and water sources had only a moderate influence on use patterns. While all households obtaining water from other households relied on sources in their immediate neighborhoods, many of them did not use the nearest improved source or stream site (Figures 2 and 3).

\section{Stream use}

Household members traveled considerably farther to the stream contact sites than to improved water sources. More than $80 \%$ of all recorded stream contacts were at the favored, less polluted 2 laundry and utensil washing sites upstream, outside the village, and the water fetching site at the upstream end of the village. The 2 other stream sites used primarily for washing utensils were on the right tributary stream in the lower section of the village. The stream sites in the center of the village, which are contaminated by the effluent of latrines, were rarely used by adults but by children for playing or fishing. Three of the 4 fish ponds containing water in November were occasionally used by children for playing and fishing (Figures 2 and 3).

\section{Maintenance and improvements of systems}

All households were asked about the nature and frequency of maintaining their water systems. All owners of wells and protected springs stated that they clean them several times a year, mostly of debris and algae, and keep the ground around these sources from becoming muddy. These labor intensive operations typically involve emptying of the wells and springs and scrubbing the stone walls with brushes.
Several owners were particularly concerned about aquatic snails and worms as possible disease-causing organisms. At least one spring was found to contain infected schistosomiasis intermediate host snails (Biomphalaria glabrata). Three new piped household connections with wash basins and showers were installed and 2 manual wells constructed during the July-November period.

\section{Simple correlation analysis}

Simple correlation analysis was carried out to examine the relationship between individual pairs of variables. House quality, the variable most strongly associated with the dependent variable liters of water fetched per person per day $(R=0.7177)$ was also significantly correlated with number of rooms, income, duration of stay in Nova União, the utility index, and latrine. All socioeconomic variables, except number of children working in agriculture and number of persons per household, were positively correlated with water use, as was the presence of a latrine. The negative correlation between number of working children and most socioeconomic variables (Table 2 ) is consistent with the smaller, poorer households lacking their own water source (Table 1). The influence of poverty on per capita water use is also borne out by the negative correlation between distance to the nearest improved water source and water use as well as all socioeconomic variables and type of water supply (Table 2).

\section{Multiple regression analysis}

A forward stepwise multiple regression analysis was used to determine the relative contribution of each of the 11 independent variables to per capita/per day water use. House quality, being the dominant variable, was first entered into the model, followed by type of water supply, latrine ownership, and the utility index, in that order. These 4 variables, all significantly associated with liters of water fetched per capita per day, explained $84.6 \%$ of the variation in the dependent variable. House quality remained significantly associated until all 10 variables were entered into the model and latrine nearly so. None of the other 6 other variables contributed significantly to the model. The variable entered last, number of rooms, contributed nothing and was deleted (Table 3). 
Table 2

Correlation matrix of the relationship between liters of water fetched per person per day (water used) and 9 independent variables.

\begin{tabular}{|c|c|c|c|c|c|c|c|c|c|c|}
\hline & (1) & (2) & (3) & (4) & (5) & (6) & (7) & (8) & (9) & $(10)$ \\
\hline \multicolumn{11}{|l|}{ Water used (1) } \\
\hline Water source (2) & $0.5470 * *$ & & & & & & & & & \\
\hline no persons (3) & -0.2077 & 0.031 & & & & & & & & \\
\hline Utility index (4) & 0.1224 & 0.0742 & 0.0457 & & & & & & & \\
\hline Latrine (5) & $0.5700 * *$ & 0.3079 & 0.1045 & 0.1820 & & & & & & \\
\hline Child work (7) & -0.249 & -0.0353 & $-0.3810 *$ & 0.2038 & -0.3037 & -0.2081 & & & & \\
\hline Education (8) & 0.07278 & 0.1932 & -0.2052 & 0.2560 & 0.2438 & 0.0554 & -0.2354 & & & \\
\hline Distance (9) & $-0.5358 * *$ & $-0.6238^{* *}$ & 0.1996 & -0.2226 & -0.1418 & 0.1113 & -0.1219 & -0.1970 & & \\
\hline House quality (10) & $0.7177^{* *}$ & $0.3553 *$ & -0.1810 & $0.4635^{* *}$ & $0.4136^{*}$ & $0.5186^{* *}$ & 0.0132 & 0.1151 & $-0.4779 * *$ & \\
\hline
\end{tabular}

*Probability $<0.05$

$* *<0.01$

Table 3

Summary of stepwise regression of independent variables significantly correlated with liters/per capita/per day.

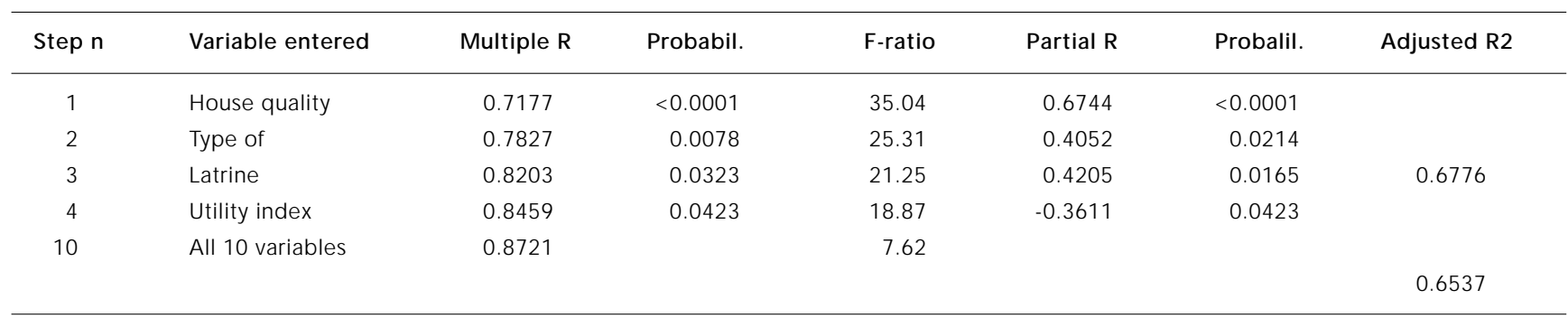

\section{Discussion and conclusion}

This study of domestic water use in a small rural community revealed some well-known and other new relationships with socioeconomic, demographic, and environmental factors. Foremost, the predominance of privately owned, constructed, and maintained water systems in Nova União village represents an effective adaptation to a poor socioeconomic environment with relatively well endowed surface and groundwater resources. Both the initiatives of individual households to construct and maintain simple, low-cost systems and their willingness to share their water sources with villagers lacking their own supply assures that basic needs for domestic water are being met, although the large variations in per capita water use among households indicate a need for additional water. The large proportion of water used for personal hygiene and sanitation in the home reflects consi derable hygiene conscious- ness in the population, in contrast to many areas in the Andean countries, where traditional hygiene practices depress water use (Sara et al., 1996).

The methodology developed here for empirical water studies has applications not only for the development of community water sources but also for the control of schistosomiasis and other water-related diseases. By spatially and statistically correlating various measures of water contact behavior and water use with infection level of households (or individuals), high-risk behavior amenable to health education may be identified at the community and neighborhood levels and the role of improved water supplies for the prevention of transmission evaluated. All earlier studies of the impact of improved water supplies on schistosomiasis in Brazil were based on the interview methods only, which cannot provide verifiable and mappable data (Kloos et al., 1997b). 
While the quantity of water fetched from the streams for home use was insignificant further indicating that improved sources are providing a fairly adequate supply for cooking and drinking frequent use of the local streams for washing clothes and utensils reveal a need for appropriate community laundry facilities. Persistent use of the streams in the presence of abundant groundwater and other improved sources was also described in Egypt and associated with water preferences, the need for appropriate physical settings (presence of rocks for beating laundry, grassy areas for drying clothes, and absence of muddy drainage water around wells and springs), and social interactions of the users, breakdown of piped systems, and long waiting lines at the community pumps (El Katsha et al., 1989; Kloos et al., 1983; Khairy, 1986). Nevertheless, wide variations in per capita per day water use among both owners and non-owners requires that the degree of their satisfaction with available supplies be determined further.

Although the private water sources in Nova União come close to what White et al. (1972) described as the "ideal case of individual management for individual families", from the point of view of cost effectiveness and maintenance, the manual wells and protected springs which are being used by various households may be at increased risk of microbial contamination, as observed elsewhere (White et al., 1972). Unimproved bucket wells, rope wells with windlass, and sources without a cement cover, all of which exist in Nova União, are particularly susceptible to contamination (Gorter et al., 1995), as is the nearness of most springs to latrines. Although residents did not consider diarrheal diseases to be a major problem, the potability of improved sources has not been determined.

The role of socioeconomic level in water use has been well established (White et al., 1972; Saunders \& Warford, 1976), but the strength of the these relationships in this small rural village lacking the socioeconomic diversity of towns comes as a surprise. This finding is particularly noteworthy in Nova União, where the cost of materials for constructing a manual well is low (20-30 Reais $=20-30 \$ U S)$. Nevertheless, the extremely low income levels of the population, also indicated by widespread child labor, renders these costs unaffordable for many households.

The use of more than one water source by many individual households has been described in other tropical areas characterized by the availability of different improved and unimproved sources (White et al., 1972; Kloos et al., 1983; 1997a, Some \& Omurwa, 1994). Use of multiple sources contributes to meeting social needs and the water requirements of households, since different types of water are preferred for different household activities, such as stream water for laundering and washing parts of the body after work in the fields and well and spring water for cooking, drinking, bathing, and other household chores.

In contrast to the improved water sources, the private latrines are hardly acceptable. Their effluent contaminates the streams with human excrement and ova of the highly prevalent S. mansoni, Ancylostoma duodenale, and Ascaris lumbricoides parasites (R. C. Oliveira, unpublished data). Moreover, absence of latrines among poor families contributes to contamination of the environment around houses and water sources. Although the family-constructed latrines were better maintained than in some Latin American externally funded water/ sanitation projects (Sara et al. 1996), latrine use remains sporadic in this agricultural community. This situation appears to be due mainly to the poverty of the population rather than traditional defecation practices, indicated by the relatively high cost of latrines and the extensive use of water for personal hygiene. In addition to raising economic levels, improvements in sanitation and health education in combination with improvements in water supplies may be a prerequisite to improving health levels, as noted elsewhere (Esrey, 1996; VanDerslice \& Briscoe, 1995).

This study indicates that direct observation, the method used to measure quantity of water drawn by non-owners from various improved sources, can yield detailed, reliable, and complete information and may thus be appropriate for use at the household level in small communities. This method, used in the past almost exclusively for water contact studies measuring risk behavior in schistosomiasis epidemiology (WHO, 1979; Kloos et al., 1990, 1997a), may thus be adapted for use in studies quantifying domestic water use in communities where water-fetching activities can be reliably observed. The presence in Nova União of households lacking their own water supply who used sources of other households and use of mainly 3 sizes of buckets $(9,12$, and 18 liters) facilitated the observation and measuring process.

This study also shows that spatial analysis, another method previously used in water contact studies (Kloos et al., 1983; 1997a), can be successfully adapted to domestic water use studies. Mapping can elucidate not only the 
role of distance on amounts of water drawn but also the relationship between water use and the distribution of different factors at the household and neighborhood levels, such as types of water sources owned and used, contamination of water sources, and social networks.

We conclude that further studies are needed in communities with different socioeco- nomic, demographic, and environmental situations to better evaluate possibilities and constraints in the improvements of rural water supplies and sanitation. Rural development planners must consider these constraints and facilitate community participation in an effort to assure the acceptability and maintenance of improved systems.

\section{Acknowledgments}

We thank the people of Nova União, particularly the observers Elias Damião, Sebastião de Assis Pereira, Isaias Damião, Ozéias Gonçalves Neto, Roberto Galdino de Souza, Edivan Martins Berto, and Geneci Galdino de Souza for their assistance with the water use study and João Teixeira Damião, Onília Damião, and Aurélio Donadia for technical assistance.

This work was supported by Small Grants/TDR/ UNDP/World Bank/WHO; Pró-Reitoria de Pesquisa da Universidade Federal de Minas Gerais - PRPq/ UFMG; Fundação de Amparo a Pesquisa de Minas Gerais - FAPEMIG, Conselho de Desenvolvimento Científico e Tecnológico - CNPq, Programa de Apoio a Grupos de Excelência - PRONEX/ CNPQ/FINEP, National Institutes of Health - NIH/ Grant AI 26505.

\section{References}

CAIRNCROSS, S., 1989. Water supply and sanitation: an agenda for research. Journal of Tropical Medicineand Hygiene, 91:301-314.

EL-KATSHA, S.; YOUNIS, A; EL-SEBAIE, O. \& HUSSEIN, A., 1989. Women, Water and Sanitation: Household Water Use in Two Egyptian Villages. Cairo: The American University of Cairo Press.

ENG, S. A.; BRISCOE, J. \& CUNNINGHAM, A., 1990. Participation effect from water projects on EPI. Social Science and Medicine, 30:1349-1358.

ESREY, S. A., 1996. Water, waste and well-being: a multicountry study. American Journal of Epidemiology, 143:608-623.

ESREY, S. A. \& HABICHT, J. P., 1986. Epidemiological evidence for health benefits from improved water supplies and sanitation in developing countries. Epidemiology Review, 8:117-128.

GIUGLIANI, E. R. J., 1989. Brazil's progress towards meeting WHO goals of health for all by the year 2000. Journal of Pediatric, 35:133-136.

GORTER, A. C.; ALBERTS, J. F.; GAGO, J. F. \& SANDIFORD, P., 1995. A randomized trial of the impact of rope-pumps on water quality. Journal of Tropical Medicineand Hygiene, 98:247-255.

HAINES, A., 1995. Primary health care at last for Brazil? (editorial). Brazilian Medical Journal, 310:1346-1347.
KHAIRY, A. M., 1986. Domestic water supplies and community self-help in Siddi-Ghazzi area-Nile Delta. Bulletin of High Institute of Health, 16:9-22.

KLOOS, H.; HIGASHI, G. I.; CATTANI, J . A.; SCHINSKI, V. D.; MANSOUR, N. S. \& MURRELL, K. D., 1983. Water contact behavior and schistosomiasis in an Upper Egyptian village. Social Science and Medicine, 17:545-562.

KLOOS, H.; HIGASHI, G. I.; SCHINSKI, V. D.; MANSOUR, N. S.; MURRELL, K. D. \& DEWOLFE MILLER, F., 1990. Water contact and Schistosoma haematobium infection: a case study from an Egyptian village. International Journal of Epidemiology, 19:749-758.

KLOOS, H.; FULFORD, A. J. C.; BUTTERWORTH, A. E.; STURROCK, R. F.; OUMA, J. H.; KARIUKI, H. C.; THIONGO, F. W.; DALTON, P. R. \& KLUMPP, R. K., 1997a. Spatial patterns of human water contact and Schistosoma mansoni transmission and infection in four rural areas in Machakos District, Kenya. Social Science and Medicine, 44:949968.

KLOOS, H.; GAZZINELLI, A.; SOUZA, M.C.C. \& NASCIMENTO, I., 1997b. Microgeographical analysis of schistosomiasis and water contact behavior: examples from Africa and Brazil. Paper presented at the Sixth International Symposium on Schisto- 
somiasis. Centro de Pesquisas René Rachou, FIOCRUZ, Belo Horizonte, October 19-24.

MOHUNDWA, E. P.Y., 1986. Rural development and primary health care in less developed countries. Social Scienceand Medicine, 22:1247-1256.

SARA, J.; GROSS, A. \& VAN DEN BERG, C., 1996. Rural Water Supply and Sanitation in Bolivia: From Pilot Project to National Program. Washington: World Bank.

SAUNDERS, R. J. \& WARFORD, J. J., 1976. VillageWater Supply: Economics and Policy in The Developing World. Baltimore: The Johns Hopkins University Press.

SAWYER, R., 1996. The Promotion of a Participatory Development Approach in theWater and Sanitation Sector. Washington: UNDP/World Bank.

SOME, E. S. \& OMURWA, T., 1994. Seasonality and community satisfaction with sources of domestic water in the Lake Victoria basin. Eastern African Medical Journal, 71:39-41.

TEKA, G. A., 1993. Water supply and sanitation. In: The Ecology of Health and Diseases in Ethiopia (H. Kloos \& Z. A. Zein, eds.), pp. 179-190. Boulder and Oxford: Westview Press.
TONIOLO, W. J., 1982. Programas de abastecimentos de água às populações de baixa renda. Revista DAE São Paulo, 42:23-28.

USAID (U.S. Agency for International Development), 1982. Domestic Water and Sanitation. PPC Policy Paper. Washington: USAID.

VANDERSLICE, J. \& BRISCOE, J., 1995. Environmental interventions in developing countries: interactions and their implications. American Journal of Epidemiology, 141:135-144.

WHITE, G. F.; BRADLEY, D. J. \& WHITE, A. U., 1972. Drawers of Water: Domestic Water Use in East Africa. Chicago: The University of Chicago Press.

WHO (World Health Organization), 1979. Workshop on the Role of Human/Water Contact in Schistosomiasis Transmission and Control. Geneva: WHO Document TDR/SER/HWC/. 3.

YEPES, G. \& DIANDERAS, A., 1996. Water and Wastewater Utilities: Indicators. 2nd Edition. Washington: World Bank. 